\title{
STRATEGIES TO IMPROVE SUSTAINABILITY IN URBAN LANDSCAPE, LITERATURE REVIEW
}

\author{
MEHDI RAKHSHANDEHROO ${ }^{1,2}$, MOHD JOHARI MOHD YUSOF ${ }^{1}$, \\ ROOZBEH ARABI ${ }^{3}$, RASUL JAHANDARFARD ${ }^{2}$ \\ ${ }^{I}$ Faculty of Design and Architecture, Universiti Putra Malaysia, 43300 Serdang, \\ Selangor, Malaysia \\ ${ }^{2}$ Department of Architecture, Beyza Branch, Islamic Azad University, Beyza, Iran \\ ${ }^{3}$ Department of Architecture, Khomein Branch, Islamic Azad University, Khomein, Iran
}

Received: $17^{\text {th }}$ May 2016, Accepted: $29^{\text {th }}$ July 2016

\begin{abstract}
Decreasing green spaces is a significant concern in today's compact cities while they provide various dimensions of sustainability; therefore, sustainable development has become the key idea to solve a series of environmental, economic and social problems. Because urban green space can be seen from different distinct disciplinary perspectives, this study reviews theories and material based on multidisciplinary and transdisciplinary approaches. Urban development and renewal should be accompanied by a green vision, to insert more plantable spaces into the urban environment. Therefore, sustainable urban planning, design and management are needed to improve urban greening by innovative and creative strategies.
\end{abstract}

Keywords: green space, open space, sustainability, urban landscape, urban planning

\section{INTRODUCTION}

Compact cities in developed and developing countries commonly face a shortage of open green space. Urban development and renewal without a green vision will miss the opportunities to create environmental relief (Steiner, 2014; Jansson \& Lindgren, 2012; Yin et al., 2011). Open green spaces provide not only aesthetic qualities but also significant ecosystem services and quality of life in the ever-shrinking environment of urban areas $(\mathrm{Wu}$, 2014; Zérah \& Landy, 2012; Woolley, 2003). Bearing in mind the increasing concerns regarding global warming and climate change cities are the focal points and urban heat islands hence urban open green spaces play a crucial role in climate control and carbon sequestration, especially in high density residential areas (Feyisa et al., 2014; Hall et al., 2012; Strohbach \& Haase, 2012). Therefore, sustainable management practices are needed to improve urban greening strategy. It is essential for both, public and private sectors to integrate plantable spaces into the urban environment. This opportunity which is laid in the smart growth and sustainable development can enhance environmental quality and improve the quality of life for millions of city dwellers (Campbell, 1996; Vasilakopoulou et al., 2014; Tuan Seik, 2001). Roadside tree planting, river and canal revitalization, green roofs (Arabi et al., 2015) and green walls (Rakhshandehroo et al., 2015; Rakhshandehroo et al., 2015) are 
all plantable recourses. Innovative greening technologies and natural and social sciences accompanied with public policies in a multidisciplinary approach are needed for sustainable development. Hence, the aim of this paper is to review multidisciplinary thought and theory concerned with sustainability goals in urban open green spaces, within the context of urban planning and landscape architecture.

\section{Problem statement: separation of humans and nature}

As settlements became bigger and more populated and nature was marginalized and neglected (Neil Stuart et al., 2013), consequently human natural aesthetic desire motivated the adaptation of ornamental plants for shielding from wind, providing shading from hot sunlight and also for natural beauty. This trend led to the establishment of domestic private gardens but they were only for the wealthy and powerful nobles and ordinary people had no access to such private facilities (Bowe, 2010). After the Industrial Revolution that brought factories and workers into cities with excessively low quality buildings, density and unhealthy environmental conditions, people demanded open green spaces to be publicly accessible. In the $19^{\text {th }}$ century local municipalities of European countries acquired some private green spaces and opened them to the public. Nowadays, public open green spaces are approved as an essential and compulsory amenity of the universal urban life (Cho et al., 2015; Lawrence, 1993).

\section{Sustainability}

Sustainability is concerned with maximizing economic and social development in a delicate balance with environmental protection and sustainable urbanism which attempts to enhance economic, social and environmental systems in towns and cities (Adhya et al., 2010; Adams, 2006). Sustainable development is the key idea to solving a series of environmental, economic and social problems, including environmental pollution, shortage of resources and overpopulation caused by urbanization. The concept of sustainable development has already covered land use, urban transport, urban ecology, social justice, socio-cultural issues and the like (Lohrasbi \& Shemshad, 2015; Zang et al., 2014)

Urban open green spaces provide a different dimension of sustainability because of opportunities for multiple benefits:

1. Social: social interaction, social cohesion, crime reduction, reduced accident probability, aesthetic regional identity, recreation, nature education, and nature experience, children's play, sport, nature education, direct health effects (mental and physical) and indirect health effects.

2. Environmental: nature conservation (ecological benefits), biodiversity and wildlife, urban climate, cooling (reduction of air temperature and urban heat islands), air flow, air quality, reduction of air pollution, carbon sequestration, noise reduction and reduction of contaminants.

3. Economic: water management (soil protection - rain water drainage), tourism, property value, food production, energy saving and enhancing workers' productivity (Lottrup, 2015).

Sustainability of open green spaces as a component of urban areas, demands an understanding of social, built, historic and geographical contexts. For example, logical distribution of greenery across urban areas provides more opportunities and associated benefits (Parés \& Sauri, 2007; Duany, 2002). In order to investigate: planning, management, development, and evaluation of a sustainable green space, this study reviewed the crucial dimensions of sustainability through environmental, social, physical, special and built characteristics, in the context of urban planning and design (Pojani \& Maci, 2015). 


\section{METHODOLOGY}

Because urban green space can be seen from different disciplinary perspectives, this study contains theories and material according to a multidisciplinary and transdisciplinary approach to encompass: urban landscape, natural resources, urban ecology, and management, urban planning and design, urban biogeography, urban horticulture and urban forestry. Computerized search was conducted by using online database such as Science Direct, Scopus, ProQuest, etc. A combination of these keywords was applied to search related papers: urban green space, open space, public space, urban environment, sustainability and sustainable development. Papers were selected from those published between the years 1994 to 2014 and they included theoretical, empirical, and reviewed ones. Literature was chosen to explain the relationship of urban green spaces and sustainability or the effect of greenery on sustainable development in urban areas (Fig. 1).

Fig. 1: Research process

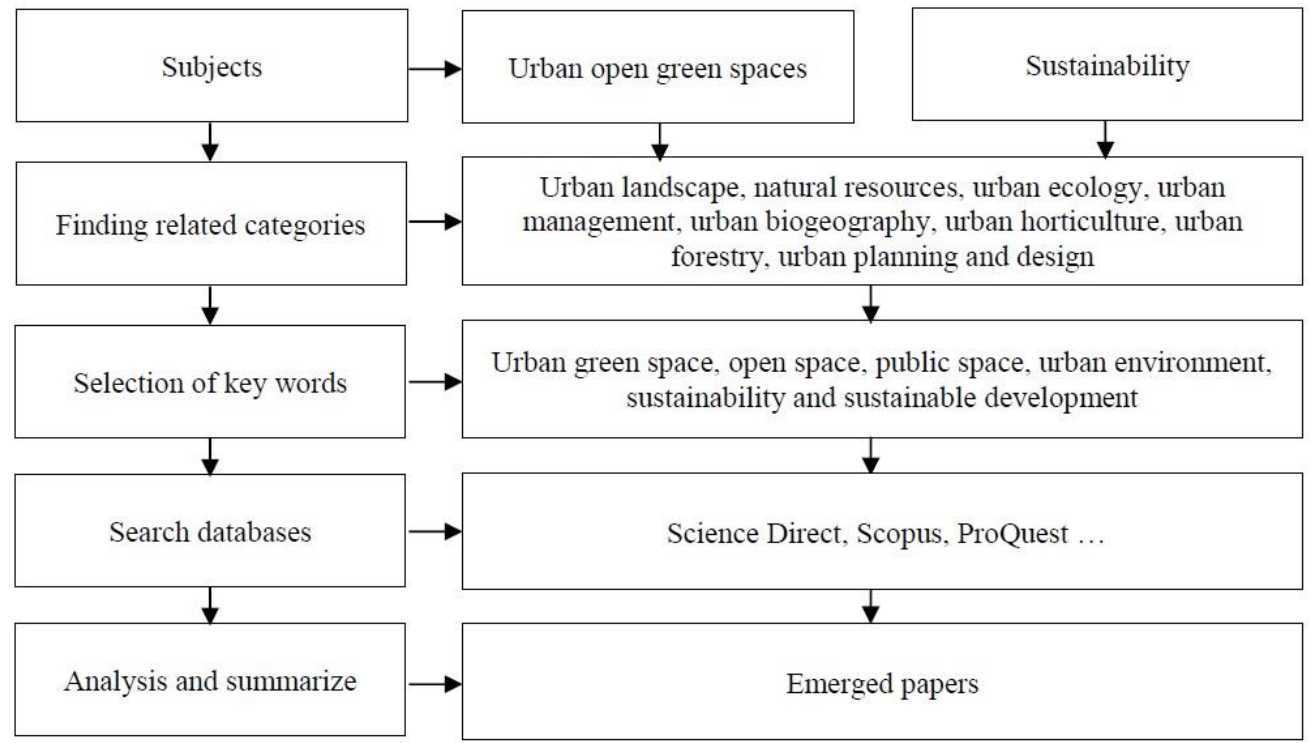

\section{OPPORTUNITIES AND CHALLENGES TO ACHIEVE SUSTAINABLE URBAN OPEN GREEN SPACES}

Some of the major opportunities and challenges facing sustainable urban open green spaces are listed below.

\section{Physical features}

\section{Size}

As a general rule, larger green areas support more animal and plant species than smaller or isolated ones. Vast green spaces, especially if scenic, are associated with an exceeded number of visitors and also physical activity (Faeth et al., 2011; Giles-Corti et al., 2005) although small neighborhood green spaces such as pocket parks can facilitate open public 
spaces where people can play with children, relax and socialize (Low et al., 2009; Jacobs, 1961).

\section{Amenity and facility:}

Facilities and amenities such as playgrounds, football field, paths or trails, sport complexes, shade structures, rest rooms, drinking fountains, and water features, as long as they are well maintained, positively influence social and environmental sustainability (Carr \& Luken, 2014; Nowak \& Heisler, 2010; Low et al., 2009).

\section{Public accessibility}

In order to reveal hidden patterns and reasons of the use or disuse by residents, it is important to study perception of belonging, comfort, and safety. Proximity of green spaces is an equity parameter that can raise physical activities and promote physical and mental health (Copeland, 2014; Poulsen et al., 2015; Giles-Corti et al., 2005). Several studies express the necessity of access to open green spaces, especially by vulnerable, minority and low income population, living in more congested and lower quality neighborhoods with fewer facilities for recreation (Sister et al., 2010). Dense neighborhoods with multi-family parcels have a higher need for public open green spaces because they are less likely to have private playgrounds. In response to environmental justice, access can be increased not only by preparing new green spaces but also by incorporating greenery and playgrounds to mixed use new developments (Talen, 2010).

\section{Vibrant space}

Urban open green spaces surrounded by dense neighborhood with various active land uses such as restaurants, hotels and shops, assistance vibrant, live public space. Busy street corners combined with street level activities such as food corners attract pedestrians and spontaneously vibrant adjacent open spaces (Mehta, 2014; Talen, 2010). By attracting "eyes on street" these spaces promote safety and prospective actual and perceived safety, supports cultural diversity in public spaces and eliminates social distinction ( $\mathrm{Li}, 2014$; Byrne \& Wolch, 2009; Jacobs, 1961).

\section{Ecological principles}

The conventional approach of open green space design is according to aesthetic or ornamental considerations of landscape architecture. The goal of open green space design is mostly to achieve a neat geometric design with limited created or inherited nature (Jim, 2013) However, urban open green spaces provide both, aesthetic qualities and ecosystem services in shrinking habitats (Kiboi et al., 2014). The ecological design could create a spatial pattern, biomass structure, community assemblage and natural species composition (Cook, 2002). On the other hand, a total wild design may not be practical, a compromise can be reached between geometrical (popular expectation) and natural design with different level of naturalness that matched the local landuse (Löfvenhaft et al., 2002).

Natural ecosystems need to be provided sufficient connections for the flow of organisms, genes, energy, materials, beyond the boundaries but they are usually surrounded by roads or built up areas. The alien and tough conditions of roads and buildings are the obstacles to wildlife movement and decrease environmental capacity to nurture and support nature (Hansen \& Pauleit, 2014; Tian \& Jim, 2011; Sorace, 2001). 


\section{UNIVERSAL STANDARDS}

Although all open green spaces may function in different local context and flexible nature, some universal standards have been found in literature. They should be welcome and accessible to a both genders, all ages, ethnic and cultural groups, with a variety of transportation facilities (walking and biking paths and public transportation) (Talen, 2006). In order to expand park uses and benefits, and enliven the space the landuses surrounding the park, should generate foot traffic (e.g. restaurants, hotels and retail shops) in populated urban area (Jacobs, 1961). They should be safe, clean, well maintained, culturally sensitive and aesthetically pleasing (Harnik, 2010).

Communities, such as students and social organizations should be involved in order to achieve the long term success because they learn and convey their experience to others, take ownership and practice on their own (Kiboi et al., 2014). They should be able to foster social interaction and cohesion while nurturing ecological function and biological diversity in geographically appropriate locations. Open green spaces can protect, support or create native habitats to support native biodiversity (Talen, 2010; Schilling, 2010). In order to enhance ecosystem services geometrical properties (e.g. size, shape, orientation, location and connectivity with other urban green spaces) could be modeled (Young, 2010). At the urban edge, verges of green areas can be extended into built up areas in an inter-connecting pattern. Wide corridors or large patches accommodate a variety of species and habitats and connectivity between them can form a green network. All in all a sustainable urban green space should contribute to sustainability not only within park boundaries but also in neighborhoods and cities by contributing both, biologicaly and to human health (Rupprecht \& Byrne, 2015; Cranz \& Boland, 2004).

\section{INTERACTION OF MULTIPLE SUSTAINABLE PARAMETERS}

In the planning of urban open green spaces, there are intercommunications between environmental, social and economic dimensions of sustainability. Although some scholars emphasize that planners should try to balance all of these dimensions, some others reason that it is impossible and unnecessary to give an equal value to all dimensions in all situations (Campbell, 1996; Larson et al., 2009). Even parks with negative environmental impact can be fruitful if they meet social and economic sustainability goals (Parés \& Sauri, 2007; Forsyth et al., 2005) propose a park design guide line to balance social and ecological benefits by emphasizing the necessity of diversity, connectivity, and access for humans and wildlife. The synergistic relationship of these two dimensions can be enhanced by simple facilities such as bird boxes in a square or a bench in urban wilderness (Rosenzweig, 2003). Sustainable park is another idea launched by (Cranz \& Boland, 2004) combining sustainable development with human well-being and providing environmental education, opportunities for social interaction, and access to nature, with emphasis on human health and landscape restoration, while facilitating public and private partnership, developing community stewardship and regional pride (Martinico et al., 2014).

\section{CONCLUSION AND RECOMMENDATIONS}

The planners and managers of urban green spaces should think creatively to find innovative ideas and opportunities to enhance greenery. For instance not only traditional green spaces (e.g. urban parks and playing fields) but also informal urban green spaces (e.g. brownfields, vacant plots, streets, and railways) are potentially a part of urban nature. 
They can play an effective role in exposing city dwellers to nature and form habitats for flora and fauna (Rupprecht \& Byrne, 2014). In order to enhance urban landscape, roadside trees are the most cost-effective and conspicuous way. A setback along roadsides could create a planting strip; A width setback, where site conditions permit, can provide space for larger trees, while medium space can accommodate small to medium trees and where space is limited in densely-packed areas, a narrow roadside planting strip could allow the growth of shrubs and herbs. A classification of different final dimensions of street tree is necessary to choose appropriate species based on the width of the planting strip.

In the compact developed areas where plantable space at the ground level is limited, the largely bare flat roof tops could be enlisted for green roof installation. Where the roof slab is strong, the intensive green roof with small trees and shrubs would provide a high-quality sky garden (Tian \& Jim, 2011). Numerous building facades and walls offer vertical greening opportunities that have hardly been realized as formal greenery. Appropriate technology and materials could be evaluated to suit local conditions (Ackley, 2014; Jim \& He, 2011). Native species, preferably flowering climbers, could be tested in field experiments. Green walls bring benefits similar to green roofs, plus the more prominent visual amenity to invigorate the cityscape.

In densely packed neighborhoods, brownfields are opportunities to become green spaces and bring relief (Doick et al., 2009) and in old urban areas, redevelopment offers chances to increase open spaces for greenery. The amenity value of old river courses or canals can make them serve as linear urban parks. By cleaning the water course in conjunction with greening of the banks they could be restored and revitalized to create blue ways bordered by greenways. Another opportunity for linear green space are railways or electricity power stations, which are laid along roads usually paved with concrete, asphalt or stones. They could be replaced with soil and herbaceous vegetation to improve the streetscape (Baron-Yelles \& Clavé, 2014; Bae, 2011).

\section{REFERENCES}

Ackley, J. W., (2014). "Bringing Nature to Humans: How to Evaluate the Next Generation of Urban Parks and Green Spaces," Cities Environ., vol. 7, no. 1, p. 9, 2014.

Adams, W. M., (2006).“The future of sustainability: Re-thinking environment and development in the twenty-first century," in Report of the IUCN renowned thinkers meeting, 2006, vol. 29, p. 31.

Adhya, A., Plowright, P. \& Stevens, J., (2010).“Defining sustainable urbanism: Towards a responsive urban design," in Proceedings of the Conference on Sustainability and the Built Environment, 2010, pp. 17-38.

Arabi, R., Shahidan, M. F., Kamal, M. S. M., Bin Jaafar, M. F. Z. \& Rakhshandehroo, M., (2015). "Mitigating Urban Heat Island Through Green Roofs," Curr. World Environ., vol. 10, no. Special Issue 1 (2015).

Bae, H., (2011).“Urban stream restoration in Korea: Design considerations and residents' willingness to pay," Urban For. Urban Green., vol. 10, no. 2, pp. 119-126, 2011.

Baron-Yelles, N. \& Clavé, S. A., (2014).“Leisure parks: components and creators of the new urban landscapes?," Loisir Société/Society Leis., vol. 37, no. 1, pp. 18-37, 2014.

Bowe, P., (2010).“The evolution of the ancient Greek garden," Stud. Hist. Gard. Des. Landscapes, vol. 30, no. 3, pp. 208-223, 2010.

Byrne, J. \& Wolch, J., (2009).“Nature, race, and parks: past research and future directions 
for geographic research,” Prog. Hum. Geogr., 2009.

Campbell, S., (1996).“Green cities, growing cities, just cities?: Urban planning and the contradictions of sustainable development,” J. Am. Plan. Assoc., vol. 62, no. 3, pp. 296-312, 1996.

Carr, V. \& Luken, E., (2014)."Playscapes: a pedagogical paradigm for play and learning," Int. J. Play, vol. 3, no. 1, pp. 69-83, 2014.

Cook, E. A., (2002).“Landscape structure indices for assessing urban ecological networks," Landsc. Urban Plan., vol. 58, no. 2, pp. 269-280, 2002.

Copeland, C., (2014).“Green Infrastructure and Issues in Managing Urban Stormwater, 2014.

Cranz, G. \& Boland, M., (2004)."Defining the sustainable park: a fifth model for urban parks," Landsc. J., vol. 23, no. 2, pp. 102-120, 2004.

Doick, K. J., Sellers, G., Castan-Broto, V. and Silverthorne, T., (2009).“Understanding success in the context of brownfield greening projects: The requirement for outcome evaluation in urban greenspace success assessment," Urban For. Urban Green., vol. 8, no. 3, pp. 163-178, 2009.

Duany, A., (2002).“Introduction to the special issue: The transect," 2002.

Faeth, S. H., Bang, C. \& Saari, S., (2011)."Urban biodiversity: patterns and mechanisms," Ann. N. Y. Acad. Sci., vol. 1223, no. 1, pp. 69-81, 2011.

Feyisa, G. L. G., Dons, K. \& Meilby, H., (2014). "Efficiency of parks in mitigating urban heat island effect: An example from Addis Ababa," Landsc. Urban Plan., vol. 123, no. 2014, pp. 87-95, 2014.

Forsyth, A., Musacchio, L. \& Fitzgerald, F., (2005). Designing small parks: A manual addressing social and ecological concerns. J. Wiley, 2005.

Giles-Corti, B., Broomhall, M. H., Knuiman, M., Collins, C., Douglas, K., Lange, K. Ng, A. and Donovan, R. J., (2005)."Increasing walking: How important is distance to, attractiveness, and size of public open space?," Am. J. Prev. Med., vol. 28, no. 2, Supplement 2, pp. 169-176, Feb. 2005.

Hall, J. M., Handley, J. F. \& Ennos, A. R., (2012).“The potential of tree planting to climate-proof high density residential areas in Manchester, UK," Landsc. Urban Plan., vol. 104, no. 3, pp. 410-417, 2012.

Hansen, R. \& Pauleit, S., (2014)."From multifunctionality to multiple ecosystem services? A conceptual framework for multifunctionality in green infrastructure planning for urban areas," Ambio, vol. 43, no. 4, pp. 516-529, 2014.

Harnik, P., (2010). Urban green: Innovative parks for resurgent cities. Island Press, 2010.

Cho, I. S., Trivic, Z. \& Nasution, I., (2015). “Towards an Integrated Urban Space Framework for Emerging Urban Conditions in a High-density Context," J. Urban Des., vol. 20, no. 2, pp. 147-168, 2015.

Jacobs, J., (1961). The death and life of great American cities. Random House LLC, 1961.

Jansson, M. \& Lindgren, T., (2012).“A review of the concept 'management' in relation to urban landscapes and green spaces: Toward a holistic understanding," Urban For. Urban Green., vol. 11, no. 2, pp. 139-145, Jan. 2012.

Jim, C. Y. \& He, H., (2011)."Estimating heat flux transmission of vertical greenery ecosystem,” Ecol. Eng., vol. 37, no. 8, pp. 1112-1122, 2011.

Jim, C. Y., (2013).“Sustainable urban greening strategies for compact cities in developing and developed economies," Urban Ecosyst., vol. 16, no. 4, pp. 741-761, Oct. 2013. 
Kiboi, S., Fujiwara, K. \& Mutiso, P., (2014)."Sustainable Management of Urban Green Environments: Challenges and Opportunities," in Sustainable Living with Environmental Risks, Springer, 2014, pp. 223-236.

Larson, K. L., Gustafson, A. \& Hirt, P., (2009).“Insatiable thirst and a finite supply: an assessment of municipal water-conservation policy in greater Phoenix, Arizona, 1980 2007, ’ J. Policy Hist., vol. 21, no. 02, pp. 107-137, 2009.

Lawrence, H. W., (1993).“The neoclassical origins of modern urban forests," For. Conserv. Hist., vol. 37, no. 1, pp. 26-36, 1993.

Li, C., (2014)."Ethnicity, Culture and Park Design: Case Studies of Urban Parks in American Chinatowns," Journal of Urban Design, vol. 19, no. 2. Taylor \& Francis, pp. 230-254, 15-Mar-2014.

Löfvenhaft, K., Björn, C. \& Ihse, M., (2002).“Biotope patterns in urban areas: a conceptual model integrating biodiversity issues in spatial planning, ” Landsc. Urban Plan., vol. 58, no. 2, pp. 223-240, 2002.

Lohrasbi, H. \& Shemshad, M., (2015)."Evaluation of Urban Green Space in Achieving Social Sustainable Development Case Study: Islamic Republic Boulevard, Karaj , Iran," vol. 3, no. 2, pp. 164-174, 2015.

Lottrup, L., Stigsdotter, U. K., Meilby, H. and Claudi, A. G., (2015).“The workplace window view: a determinant of office workers' work ability and job satisfaction," Landsc. Res., vol. 40, no. 1, pp. 57-75, 2015.

Low, S., Taplin, D. \& Scheld, S., (2009). Rethinking urban parks: Public space and cultural diversity. University of Texas Press, 2009.

Martinico, F., La Rosa, D. \& Privitera, R., (2014). "Green oriented urban development for urban ecosystem services provision in a medium sized city in southern Italy," iForest-Biogeosciences For., vol. 7, no. 7, p. 385, 2014.

Mehta, V., (2014).“Evaluating public space,” J. Urban Des., vol. 19, no. 1, pp. 53-88, Jan. 2014.

Neil Stuart, D. M., Robert, L., Hodgart, L., Mohd Johari Mohd Yusof, (2013). “Towards a better understanding of urban green infrastructure," RICS Res., 2013.

Nowak, D. J. \& Heisler, G. M., (2010). “Air Quality Effects of Urban Trees and Parks,” Natl. Recreat. Park Assoc., 2010.

Parés, M. \& Sauri, D., (2007). "Integrating sustainabilities in a context of economic, social, and urban change," Sustain. Dev. Parad., pp. 160-191, 2007.

Pojani, D. \& Maci, G., (2015)."The Detriments and Benefits of the Fall of Planning: The Evolution of Public Space in a Balkan Post-socialist Capital," J. Urban Des., vol. 20, no. 2, pp. 251-272, 2015.

Poulsen, D. V., Stigsdotter, U. K. and Refshage, A. D., (2015).“Whatever happened to the soldiers? Nature-assisted therapies for veterans diagnosed with post-traumatic stress disorder: A literature review," Urban For. Urban Green., vol. 14, no. 2, pp. 438-445, 2015. Rakhshandehroo, M., Yusof, M., Johari, M. and Arabi, R., (2015).“Living wall (vertical greening): Benefits and Threats.," in Applied Mechanics and Materials, 2015, vol. 747, pp. 16-19.

Rakhshandehroo, M., Yusof, M., Johari, M. and Deghati Najd, M., (2015).“Green Façade (Vertical Greening): Benefits and Threats," in Applied Mechanics and Materials, 2015, vol. 747 , pp. $12-15$. 
Rosenzweig, M. L., (2003)."Reconciliation ecology and the future of species diversity," Oryx, vol. 37, no. 02, pp. 194-205, 2003.

Rupprecht, C. D. D. \& Byrne, J. A., (2014). Informal Urban Green-Space: Comparison of Quantity and Characteristics in Brisbane, Australia and Sapporo, Japan," PLoS One, vol. 9, no. 6, p. e99784, 2014.

Rupprecht, C. D. D. \& Byrne, J. A., (2015).“Informal urban green space: A trilingual systematic review of its role for biodiversity and trends in the literature," Urban For. Urban Green., vol. 14, no. 4, pp. 883-908, 2015.

Schilling, J., (2010).“Towards a Greener Green Space Planning.” Thesis, Lund University, International Master's Programme in Environmental Studies and Sustainability Science, 2010.

Sister, C., Wolch, J. \& Wilson, J., (2010).“Got green? Addressing environmental justice in park provision,” GeoJournal, vol. 75, no. 3, pp. 229-248, 2010.

Sorace, A., (2001)."Value to wildlife of urban-agricultural parks: a case study from Rome urban area," Environ. Manage., vol. 28, no. 4, pp. 547-560, 2001.

Steiner, F., (2014). "Frontiers in urban ecological design and planning research," Landsc. Urban Plan., 2014.

Strohbach, M. W. \& Haase, D., (2012).“Above-ground carbon storage by urban trees in Leipzig, Germany: Analysis of patterns in a European city,” Landsc. Urban Plan., vol. 104, no. 1, pp. 95-104, 2012.

Talen, E., (2006)."Design that enables diversity: the complications of a planning ideal," J. Plan. Lit., vol. 20, no. 3, pp. 233-249, 2006.

Talen, E., (2010).“The spatial logic of parks,” J. Urban Des., vol. 15, no. 4, pp. 473-491, 2010.

Tian, Y. \& Jim, C. Y., (2011). "Factors influencing the spatial pattern of sky gardens in the compact city of Hong Kong," Landsc. Urban Plan., vol. 101, no. 4, pp. 299-309, 2011.

Tuan Seik, F., (2001)."Planning and design of Tampines, an award-winning high-rise, high-density township in Singapore," Cities, vol. 18, no. 1, pp. 33-42, 2001.

Vasilakopoulou, K., Kolokotsa, D. \& Santamouris, M., (2014).“Cities for Smart Environmental and Energy Futures: Urban Heat Island Mitigation Techniques for Sustainable Cities," in Cities for smart environmental and energy futures, Springer, 2014, pp. 215-233.

Woolley, H., (2003). Urban open spaces. Taylor \& Francis, 2003.

Wu, J., (2014). "Public open-space conservation under a budget constraint," J. Public Econ., no. 2014, Jan. 2014.

Yin, S., Shen, Z., Zhou, P., Zou, X., Che, S. and Wang, W., (2011). "Quantifying air pollution attenuation within urban parks: An experimental approach in Shanghai, China," Environ. Pollut., vol. 159, no. 8, pp. 2155-2163, 2011.

Young, V, (2010)."Managing municipal green space for ecosystem services," Urban For. Urban Green., vol. 9, no. 4, pp. 313-321, 2010.

Zang, X., Tian, C. and Qiao, W., (2014).“'Construction of Sustainable Development Indicator System of Green Blocks,” Bridges, vol. 10, pp. 9780784478745-054, 2014.

Zérah, M. \& Landy, F., (2012).“Geoforum Nature and urban citizenship redefined: The case of the National Park in Mumbai q," vol. 46, no. 2013, pp. 25-33, 2012. 